\title{
降圧薬服用患者における特徴的歯肉増殖の発症調査
}

\author{
薬師寺 登・宮 本 博 文・高砂 清 隆 \\ 石井庄一郎 ${ }^{*} \cdot 川$ 本眞奈美 ${ }^{* *}$
}

\section{Prevalence survey of peculiar gingival hyperplasia in patients treated with antihypertensive agents}

\author{
Noboru YakUShIJI $\cdot$ Hirofumi MiYamoto $\cdot$ Kiyotaka TAKASAgo \\ Syoichirou Ishis* ${ }^{*}$ Manami KaWAmoto**
}

\begin{abstract}
The prevalence of peculiar gingival hyperplasia was studied periodontically in 169 patients treated with antihypertensive agents. A total of 129 patients were receiving calcium antagonists and the other 40 were receiving other types of antihypertensive agents.

Gingival hyperplasia was observed in $19 \%$ of the patients in the calcium antagonist group. There was no clear relationship between oral hygiene indexes and the occurrence of gingival hyperplasia. Among patients in the calcium antagonist group, there was no significant difference in the duration of treatment between those with gingival hyperplasia and those with no gingival hyperplasia.

The results suggest that the peculiar gingival hyperplasia associated with calcium antagonists is not related only to the dose of these drugs.
\end{abstract}

Key words: gingival hyperplasia (歯肉増殖), calcium antagonist (カルシウム拮抗薬), antihypertensive agent (降圧薬), prevalence survey (発症調査)

\section{緒言}

近年, 循環器疾患において汎用されているニフェジ ピンにより歯肉増殖が見られるとの報告が散見される ようになった1〜3). さらに, 他のカルシウム拮抗薬に も歯肉增殖が報告されている4,5). しかしながら，カ ルシウム拮抗薬投与患者のすべてに歯肉増殖が認めら れるわけではない. 本症に関して本邦での発症調査は, われわれの渉隠した限りでは, 岩倉ら ${ }^{6)}$ の報告のみで ある.

そこで, 高血圧症, 狭心症等に対し, 本剤は本邦で 最も汎用されていることから, 歯肉増殖の発生頻度の
把握が必要であると考え発症調査を施行したので報告 する。

\section{調查対象および方法}

\section{1. 調查対象}

当院併設の—外来において降圧薬 を服用している患者のうち, 有歯顎者 169 名（男性 87 名, 女性 82 名）に対して口腔診査を実施した。年龄は 35-75 歳で, 男性の平均年齢は 59.2 55.2 歳, 女性の平 均年歯は $58.3 \pm 6.3$ 歳で, 調查対象全体の平均年齢は $59.0 \pm 5.5$ 歳であった（表 1 ).
公立学校共済組合近畿中央病院歯科口腔外科

(主任 : 薬師寺 登部長)

*大阪大学歯学部口腔外科学第 1 講座

（主任 : 松矢篤三教授）

**大阪厚生年金病院歯科口腔外科

(主任 : 西村敏治部長)

Department of Dentistry and Oral Surgery, Kinki Central Hospital (Chief: Noboru
Yakushiji)

* First Department of Maxillo-Facial Surgery, School of Dentistry, Osaka University (Chief: Prof. Tokuzo Mastuya)

** Department of Dentistry and Oral Surgery, Osaka Koseinenkin Hospital (Chief: Toshiharu Nishimura)

受付日：平成 8 年 1 月 9 日 
表 1 調査対象

\begin{tabular}{cccc}
\hline & & 被験者数 (名) & 平均年齢（歳） \\
\hline 男 性 & 87 & $59.2 \pm 5.2$ \\
女 性 & 82 & $58.3 \pm 6.3$ \\
\hline 合 計 & 169 & $59.0 \pm 5.5$ \\
\hline
\end{tabular}

表 2 降圧剂別調査対象

\begin{tabular}{lcc}
\hline & カルシウム拮抗薬群 & 他の降圧薬群 \\
\hline 男性 (名) & 68 & 27 \\
平均年齢 (歳) & $58.3 \pm 6.8$ & $60.5 \pm 7.3$ \\
女性 (名) & 61 & 13 \\
平均年齢 (歳) & $59.4 \pm 5.6$ & $57.1 \pm 6.8$ \\
\hline 合計 (名) & 129 & 40 \\
平均年齢 (歳) & $59.0 \pm 6.0$ & $58.8 \pm 7.0$ \\
\hline
\end{tabular}

\section{2. 口腔診查}

口腔診查は, 特徵的歯肉増殖の有無を判定し, DI-S, CI-S を計測し OHI-S を算定し，さらに口腔内写真を 一人当たり 5 枚撮影し記録した。

\section{3 . 特幑的歯肉增殖の判定}

特徵的歯肉増殖の判定は, 岩倉ら ${ }^{6}$ )の判定基準に基 づき「通常の歯周炎あるいは歯肉炎と区別できる歯肉 増殖が多発性に認められ，かつ，その増殖は局所的な 原因では説明できない特徵的増殖と思われるもの」と した.この判定に合致したものを歯肉增殖「あり」, 歯 肉が正常のもの，あるいは, この判定に合致しないも のを歯肉増殖「なし」と分類した. 判定に際しては, 撮影した口腔写真を最終判定に使用し, 一人の歯科医 師が分類した。

\section{4. 服薬調査}

被験者のカルテから, 降圧薬服用歷を調査し, 複数 の降圧薬服用の既往のあるもの，および抗てんかん薬 服用の既往のある者は除外し, 現在服用中の降圧薬の 種類, 服用期間について記録した.

統計学的有意差の検定には, Fisher の直接確率計算, $\chi^{2}$ 検定および $\mathrm{t}$ 検定を用いた。

\section{結果}

調査対象とした 169 名のうち菌肉増殖は 25 名に認 められた. 169 名のうち 129 名がカルシウム拮抗薬服 用患者（男性 68 名，女性 61 名）で，40名が他の降圧 薬 (アテノロール, アラセプリル, 塩酸デラプリル, リ シノプリル）を服用中であった（表 2 ）. 服用中のカル シウム拮抗薬の種類は, ニカルジピン 41 名, ニフェジ ピン 35 名, ベニジピン 28 名, ニトレンジピン 5 名, 二
表 3 降圧剂別歯肉増殖の発現

カルシウム拮抗薬群 他の降圧薬群

\begin{tabular}{lcccc} 
歯肉增殖 & あり & なし & あり & なし \\
\hline 男性 (名) & 15 & 53 & 0 & 27 \\
平均年齢 (歳) & $59.3 \pm 4.6$ & $58.3 \pm 6.8$ & & $60.5 \pm 7.3$ \\
女性 (名) & 10 & 51 & 0 & 13 \\
平均年齢 (歳) & $58.3 \pm 7.1$ & $59.4 \pm 5.6$ & & $57.1 \pm 6.8$ \\
\hline 合計 (名) & 25 & 104 & 0 名 & 40 \\
平均年齢 (歳) & $57.3 \pm 5.1$ & $59.0 \pm 6.0$ & & $58.8 \pm 7.0$ \\
\hline
\end{tabular}

表 4 口腔清掃状態の比較

\begin{tabular}{l|ccc}
\hline 蒾肉增殖 & $\mathrm{DI}-\mathrm{S}$ & $\mathrm{CI}-\mathrm{S}$ & $\mathrm{OHI}-\mathrm{S}$ \\
\hline 認める $\mathrm{n}=25$ & $0.7 \pm 0.3$ & $0.6 \pm 0.2$ & $1.3 \pm 0.4$ \\
認めない $\mathrm{n}=104$ & $0.8 \pm 0.4$ & $0.6 \pm 0.3$ & $1.4 \pm 0.4$ \\
\hline
\end{tabular}

ソルジピン 6 名, ニルバジピン 8 名, ジルチアゼム 6 名であった。

歯肉増殖はカルシウム拮抗薬群にのみ認められ, 他 の降圧薬群には認められなかった. カルシウム拮抗薬 群において, 歯肉增殖の発現に男女間の有意の差は認 められなかった（表 3 ).

次いで, カルシウム拮抗薬群において, DI-S, CI-S, およびOHI-S を歯肉増殖を認める群と, 認めない群 において比較した，その結果，いずれの調査項目にお いても両者に有意の差は認められなかった（表 4 ）.

25 名の歯肉増殖を認める群において, 服用中のカル シウム拮抗薬は, ニカルジピン 8 名, ニフェジピン 7 名, ベニジピン 5 名, ニトレンジピン 1 名, ニソルジピ ン 1 名, ニルバジピン 1 名, ジルチアゼム 2 名で, 今回 調查したすべてのカルシウム拮抗薬において歯肉増殖 の発現が認められた。

カルシウム拮抗薬の投薬期間は, 歯肉增殖を認める 群： 5 か月～93 か月 (平均 27.3 か月), 歯肉增殖を認 めない群は 1 か月 60 か月 (平均 22.7 か月) で, 両群 の投薬期間に有意差を認めなかった. しかしながら， ニカルジピン投薬群では歯肉増殖を認める群に有意に 投薬期間が長く, ニフェジピン投薬群では逆に歯肉増 殖を認めない群に有意に投薬期間が長くなっていた (表 5 ).

\section{考察}

カルシウム拮抗薬, 特にニフェジピンが原因と考え られる歯肉增殖は, 1984 年の Ramon ら ${ }^{1)}$ 以来たび たび報告されるようになった。 
表 5 カルシウム拮抗薬別の歯肉増殖の発現

\begin{tabular}{|c|c|c|c|c|}
\hline & \multicolumn{2}{|c|}{ 歯肉増殖を認める群 } & \multicolumn{2}{|c|}{ 歯肉増殖を認めない群 } \\
\hline & 症例数 & 投与期間（か月） & 症例数 & 投与期間 (か月) \\
\hline ニカルジピン & 8 & $41.2 \pm 6.8$ & 33 & $25.8 \pm 5.3$ \\
\hline ニフェジピン & 7 & $29.1 \pm 5.1$ & 28 & $39.9 \pm 7.3$ \\
\hline ベニジピン & 5 & $15.8 \pm 4.2$ & 23 & $10.1 \pm 4.9$ \\
\hline ニトレンジピン & 1 & 6 & 4 & $15.5 \pm 8.3$ \\
\hline ニソルジピン & 1 & 23 & 5 & $27.1 \pm 4.3$ \\
\hline ニルバジピン & 1 & 8 & 7 & $14.4 \pm 8.9$ \\
\hline ジルチアゼム & 2 & 16.5 & 4 & $6.2 \pm 0.7$ \\
\hline 合 計 & 25 & $27.3 \pm 5.3$ & 104 & $22.7 \pm 6.5$ \\
\hline
\end{tabular}

今回の調查では, まず, カルシウム拮抗薬群と他の 降圧薬群において歯肉增殖の有無を比較した。 その結 果, カルシウム拮抗薬群にのみ特徵的歯肉増殖が認め られ, さらに, 今回調査したすべての種類のカルシウ 厶拮抗薬群に歯肉増殖が認められた。このことから， 降圧薬の中でもカルシウム拮抗薬服用患者に歯肉増殖 が発現することが明らかとなった。 また，このカルシ ウム拮抗薬群における歯肉増殖発現の頻度は, 129 名 中 25 名, 約 $19 \%$ であり，現在まで報告されているカル シウム拮抗薬の他の副作用と比較して, 著しく高い頻 度であると考えられた。

この歯肉増殖に関して興味深いことは, 無歯顎の歯 肉には見られないということである。すなわち，発現 する部位は歯の存在する部位で, 特に辺縁の不適合な ブリッジやダミーの下部に発現する1〜5) ことから， 辺縁性歯周炎を基盤として発生するのではないかと考 えられている。しかしながら，今回の調査では，口腔 清掃状態の指標として, DI-S, CI-S を計測し, OHI-S を算定したが, 歯肉増殖を認める群と, 認めない群と の間に，いずれの項目においても有意差を認めず，口 腔衛生状態が直接的に歯肉増殖の発現に関係している 事実は認めなかった。

慢性的な薬剂の副作用は一般的に容量依存性の反応 であるのに対し，本症は投与量と投与期間が発現の有 無に関連しないという報告がある ${ }^{3,6)}$. 今回の調査で は，歯肉増殖が認められた最短投薬期間は 5 か月であっ た.また, ニカルジピン投薬群では歯肉増殖を認める 群に投薬期間が長く,ニフェジピン投薬群では逆に歯 肉增殖を認めない群に投薬期間が長い結果となった。 さらに, カルシウム拮抗薬投薬群全体の比較では両群 の投薬期間には有意差は認められなかった。これらの ことは, 歯肉増殖が単なる容量依存性の反応でないこ とを示唆するものであると考えられた。

\section{結 \\ 語}

降圧薬服用患者 169 名について特徵的歯肉増殖の発 症調查を施行した.カルシウム拮抗薬服用患者は 129 名で, 他の降圧薬服用患者は 40 名であった.このうち, カルシウム拮抗薬群の 129 名中 25 名 (19\%) に特徵的 な歯肉増殖が認められた. 歯肉増殖とカルシウム拮抗 薬投薬期間には, 有意な関係は認められず, この増殖 が単なる容量依存性の反忘でないことが示唆された。

また，この増殖の発現に口腔衛生状態が関与してい るという根拠は認められなかった。

本研究にあたり, 御指導, 御協力いただきました本院高 血圧センター村上英紀センター長, 臨床検査科山下憲一 部長に感謝します。

本論文の一部は, 第 40 回 (社) 日本口腔外科学会総会 （1995 年 10 月東京）にて発表した。

\section{引用文 献}

1) Ramon, Y., Behar, S., et al.: Gingival hyperplasia caused by nifedipine a preliminary report. Int. J. Cardiol. 5 : 1952041984

2）川本眞奈美, 薬師寺 登, 他：ニフェジピンに よる歯肉增殖症の 1 症例. 近中病院雑誌 16: 35371994.

3）佐藤田鶴子, 内川裕之, 他：ニフェジピンによ る歯肉增殖症の 1 症例ならびに文献的考察。日 口外誌 34: 2025-2030 1988.

4) Cucchi, G., Giustiniani, S., et al.: Ital. Cardiol., 15: 556-557 1985.

5) Giustunianl, S., Robustelli della Cuna, F., et al.: Int. J. Cardiol., 15: 247-249 1987.

6）岩倉政城, 渋谷芳郎, 他 : ニジェジピン（血圧 降下剂）療法を受けている患者の歯肉增殖状況 について. 口腔衛生会誌 37: 574-575 1987 . 